\title{
FAKTOR- FAKTOR YANG MEMPENGARUHI PENYUSUNAN ANGGARAN PENDAPATAN \\ DAN BELANJA DAERAH BERBASIS KINERJA DI PEMERINTAH KOTA SORONG
}

\author{
Santrinita.Trh.Jumame \\ Herman karamoy \\ Agus T Poputra \\ santrinitayumame@yahoo.co.id
}

\begin{abstract}
The objective of this is to test empirically and analyze whether commitment factor of all organizational component, perfection of administration system, enough human resources, transparent reward and firm punishment have an effect on budgeting of regional revenue and expenditure based on performance.

The population on this research are the chiefs of work unit of regional public service and the chief of planning division of work unit of regional public service in government of Kota Sorong regency that amount to 70 person, where all of them become the sample. To test hypothesis of commitment influence ,of all organization component. the perfection of administration system, sufficient human resources, transparent reward, and firm punishment have effect on budgeting of regional revenue and expenditure $(A P B D)$ based on performance simultaneously and partially used F test and $t$ test.

The result of this research proves that the commitment of all organization component, the perfection of administration system, sufficient human resources, transparent reward and firm punishment have an effect on significant budgeting of regional revenue and expenditure (APBD) based on performance simultaneously, but the one the end partially the perfection of administration system, sufficient human resources, transparent reward the biggest influence to budgeting of regional revenue and expenditure (APBD) based on performance is the perfection of administration system.

Keywords : Commitment of all organization component, The perfection of administration system, sufficient human resources, Transparan reward, and Firm punishment.
\end{abstract}

\section{PENDAHULUAN}

\subsection{Latar Belakang}

Dalam penyusunan Anggaran Berbasis kinerja yang diterbitkan Badan Pengawasan Keuangan dan Pembangunan (BPKP) tahun 2005 dinyatakan: tuntutan pentingnya pelaksanaan penyusunan anggaran berbasis kinerja, ternyata membawa konsekuensi yang harus disiapkan beberapa faktor- faktor keberhasilan implementasi penggunaan anggaran berbasis kinerja, yaitu sebagai berikut.

1. Gaya kepemimpinan dan komitmen dari seluruh komponen organisasi

2. Penyempurnaan sistem administrasi secara terus menerus

3. Sumber daya yang cukup

4. Penghargaan (reward)yang jelas dan

5. sanksi(punishment)yang tegas

Dengan adanya ke (5) faktor-faktor keberhasilan implementasi penggunaan anggaran berbasis kinerja (ABK) ini dapat berpengaruh positif terhadap penyusunan APBD Berbasis Kinerja di Pemerintah Kota Sorong. Sehingga pada gaya kepemimpinan dan komitmen dari seluruh komponen organisasi, penyempurnaan sistem administrasi secara terus-menerus, sumber daya yang cukup, reward dan punishment, menjadi indicator pencapaian pengukuran kinerja yang dapat mencapai tujuan untuk meningkatkan efektivitas penggunaannya sesuai dengan perencanaan yang ditetapkan oleh Pemerintah Pusat dan Pemerintah Daerah.

Penyusunan anggaran berbasis kinerja bertujuan untuk dapat meningkatkan efisiensi pengalokasian sumber daya dan efektivitas penggunaannya sesuai dengan perencanaan yang telah ditetapkan oleh pemerintah daerah sehingga dengan adanya anggaran berbasis kinerja tersebut diharapkan anggaran dapat digunakan secara optimal untuk meningkatkan kesejahteraan masyarakat dan dapat mendukung peningkatan transparansi dan akuntabilitas manajemen sektor publik. Selain itu, anggaran 
berbasis kinerja memfokuskan pemanfaatan anggaran untuk perbaikan kinerja organisasi yang berpedoman pada prinsip value for money.

Pemerintah Kota Sorong telah menyesuaikan struktur APBD secara bertahap sesuai dengan peraturan yang berlaku terutama pergeseran sistem anggaran tradisional ke sistem berbasis kinerja sesuai dengan Peraturan Pemerintah Nomor 105 tahun 2000 yang telah diubah dengan Peraturan Pemerintah Nomor 58 tahun 2005 tentang pengelolaan keuangan daerah. Pada tahun 2003 dan sebelumnya penyusunan APBD Kota Sorong menggunakan sistem MAKUDA (line item dan incremental) yang disusun secara lebih sederhana. Tahun 2008 penyusunan APBD Kota Sorong menyesuaikan dengan sistem Anggaran Berbasis Kinerja.

\subsection{Perumusan Masalah}

Berdasarkan latar belakang yang diuraikan diatas, maka rumusan masalah pada penelitian ini adalah sebagai berikut:

1. Apakah Pengaruh factor gaya kepemimpinan dan komitmen dari seluruh komponen organisasi terhadap penyusunan APBD Berbasis Kinerja Pemerintah Kota Sorong?

2. Apakah Pengaruh factor penyempurnaan sistem administrasi secara terus-menerus terhadap penyusunan APBD Berbasis Kinerja Pemerintah Kota Sorong?

3. Apakah Pengaruh faktor sumber daya yang cukup terhadap penyusunan APBD Berbasis Kinerja Pemerintah Kota Sorong?

4. Apakah Pengaruh faktor Reward (penghargaan) terhadap penyusunan APBD Berbasis Kinerja Pemerintah Kota Sorong?

5. Apakah Pengaruh factor Punishment (hukuman/ sanksi) terhadap penyusunan APBD Berbasis Kinerja Pemerintah Kota Sorong?

\subsection{Tujuan Penelitian}

1. Untuk menganalisis pengaruh faktor gaya kepemimpinan dan komitmen dari seluruh komponen organisasi terhadap penyusunan APBD Berbasis Kinerja Pemerintah Kota Sorong.

2. Untuk menganalisis pengaruh faktor penyempurnaan sistem administrasi secara terus-menerus terhadap penyusunan APBD Berbasis Kinerja Pemerintah Kota Sorong.

3. Untuk menganalisis pengaruh faktor sumber daya yang cukup terhadap penyusunan APBD Berbasis Kinerja Pemerintah Kota Sorong.

4. Untuk menganalisis pengaruh faktor Reward (penghargaan) yang jelas terhadap penyusunan APBD Berbasis Kinerja Pemerintah Kota Sorong.

5. Untuk menganalisis pengaruh faktor Punishment (hukuman/ sanksi) yang tegas terhadap penyusunan APBD Berbasis Kinerja Pemerintah Kota Sorong.

\subsection{Manfaat Penelitian}

1. Dapat menjadi masukan-masukan kepada SKPD Kota Sorong sebagai bahan pertimbangan pemerintah daerah dalam Pengelolaan Keuangan Daerah untuk melakukan penyempurnaan sistem dan perbaikan kebijakan dalam penyusunan APBD Berbasis Kinerja, untuk pencapian visi dan misi, tujuan serta sasaran yang berkaitan dengan pemahaman tentang indicator anggaran berbasis kinerja.

2. Dapat menambah literature bagi pihak- pihak yang akan melakukan studi terkait atau penelitian selanjutnya.

3. Menambah khazanah penelitian empirirs terkait anggaran pendapatan dan belanja daerah.

\section{TINJAUN PUSTAKA}

a. Landasan Teori

Menurut Mulyadi (2001-488) anggaran merupakan suatu rencana kerja yang dinyatakan secara kuantitatif yang diukur dalam satuan moneter standar dan satuan ukuran yang lain yang mencakup jangka waktu satu tahun. Menurut Supriyono (1990-15), penganggaran merupakan perencanaan keuangan perusahaan yang dipakai sebagai dasar pengendalian (pengawasan) keuangan perusahaan untuk periode yang akan datang. Sementara itu menurut UU pemerintah Nomor 17 tahun 2003 anggaran adalah alat akuntanbilitas manajemen, dan kebijakan ekonomi. Sebagai instrument kebijakan ekonomi, anggaran berfungsi untuk 
mewujudkan pertumbuhan dan stabilitas perekonomian serta pemerataan pendapatan dalam rangka mencapai tujuan bernegara.

\section{b. Mekanisme Penyusunan Keuangan Daerah (APBD)}

Salah satu aspek penting dalam pengelolaan pemerintah daerah adalah penyusunan anggaran daerah. Hal ini dikarenakan anggaran daerah merupakan uang rakyat yang dititipkan kepada daerah untuk dikelola guna memenuhi kebutuhan pelayanan publik sehingga menyangkut hajat hidup orang banyak. Bila kualitas pengelolaannya rendah maka kebutuhan public tidak optimal apalagi jika terjadi penyimpanganpenyimpangan seperti adanya korupsi dan manipulasi. Untuk mengantisipasi segala kemungkinan dalam penyusunan Anggaran Pendapatan dan Belanja Daerah (APBD) partisipasi masyarakat sangat dibutuhkan. Keterlibatan masyarakat diharapkan akan menghasilkan anggaran yang aspiratif artinya apa yang dianggarkan dalam APBD adalah mencerminkan kebutuhan masyarakat bukan untuk kepentingan kelompok tertentu.

\section{c. Faktor-faktor Keberhasilan Implementasi Penggunaan Anggaran Berbasis Kinerja}

Secara teoritis, kepemimpinan (leadership) merupakan hal yang sangat penting dalam manajerial, karena kepemimpinan yang baik maka proses manajemen akan berjalan dengan baik dan pegawai akan bergairah dalam melakukan tugasnya (Widiyantora 2005),faktor kepemimpinan memainkan peranan yang sangat penting dalam keseluruhan upaya untuk meningkatkan kinerja, baik pada tingkat kelompok maupun dalam tingkat organisasi. Menurut (Kunwaviyah dan Machmud 2010), komitmen organisasi merupakan tingkat sampai sejauh mana seorang karyawan memihak pada suatu organisasi tertentu dan tujuan-tujuannya, serta berniat untuk mempertahankan keanggotaannya dalam organisasi. Sejalan dengan teori yang dikemukakan oleh Randal (1990) dalam Sardjito (2007) komitmen organisasi yang tinggi akan meningkatkan kinerja yang tinggi pula.

Demikian pula menurut Tjokroamidjojo (1985),dalam kutipan Sinaga (2008) bahwa reformasi administrasi perlu ditujukan pada penyempurnaan administrasi untuk mendukung pembangunan daerah. Penyempurnaan administrasi secara berkelanjutan berupa penyiapan instrument pengukuran anggaran berbasis kinerja secara terus menerus melalui penyempurnaan instrument pengukuran anggaran berbasis kinerja yang sudah ada yaitu standar pelayanan minimal, standar analisis belanja, target kinerja dan standar biaya merupakan factor penting dalam keberhasilan penyusunan APBD berbasis kinerja. Hal ini sesuai Peraturan Menteri Dalam Negeri Nomor 59 Tahun 2007 pasal 100 ayat (2) dan (3).

Sumber daya yang cukup yaitu upaya penyediaan sarana dan prasarana peningkatan kualitas implementasi anggaran berbasis kinerja (sembiring 2009) sumber daya yang cukup disini adalah termasuk uang, waktu dan orang yang akan melakukan proses penganggaran berbasis kinerja. Ada dua elemen mendasar yang berkaitan dengan pengembangan sumber daya manusia yaitu tingkat pendidikan dan keterampilan yang dimiliki oleh pekerja (Kusdayah 2008).

Menurut Nugroho (2006)Reward dan Punishment merupakan dua bentuk metode dalam memotivasi seseorang untuk melakukan kebaikan dan meningkatkan prestasinya dalam hal implementasi anggaran berbasis kinerja ini perlu dijaga konsistensi perencanaan dengan penganggaran dan pemberian reward dan punishment yang jelas bagi satuan kerja perangkat daerah. Dari uraian tersebut hasil penelitian yang dilakukan menunjukkan bahwa faktor penghargaan (reward) berpengaruh positif sebagai faktor-faktor yang mempengaruhi penyusunan APBD berbasis kinerja. 


\section{Hipotesis}

$\mathrm{H}_{1}$ : Kepemimpinan dan komitmen dari seluruh komponen organisasi merupakan faktor-faktor yang berpengaruh terhadap penyusunan APBD berbasis kinerja.

$\mathrm{H} 2$ : Penyempurnaan sistem administrasi merupakan faktor-faktor yang berpengaruh terhadap penyusunan APBD berbasis kinerja.

H3 : Sumber daya yang cukup merupakan faktor-faktor yang berpengaruh terhadap penyusunan APBD berbasis kinerja.

H4 : Reward(penghargaan) merupakan factor-faktor yang mempengaruhi penyusunan APBD berbasis kinerja.

H5 : Punishment (hukum/sanksi) merupakan faktor-faktor yang berpengaruh terhadap penyusunan APBD berbasis kinerja.

\section{METODE PENELITIAN}

\subsection{Populasi dan Sampel}

Populasi dalam penelitian ini adalah seluruh satuan kerja perangkat daerah Kota Sorong terdiri dari 70 responden yang dibagi masing-masing kepada seluruh SKPD sebagai responden dengan alasan karena mereka dianggap orang yang ikut terlibat dalam penyusunan anggaran pada satuan kerja perangkat daerah (SKPD) pemerintah kota sorong yang menjadi objek penelitian ini.

\subsection{Model Analisi Data}

Pengolahan data meuggunakan software SPSS. Model analisis regresi linier berganda dalam penelitian ini dapat dirumuskan adalah sebagai berikut.

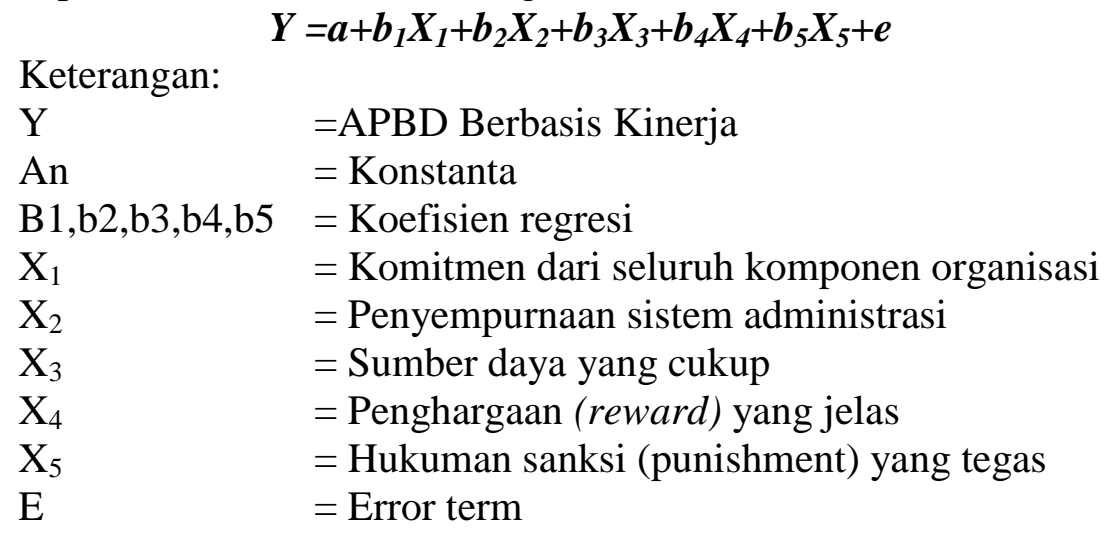

\subsection{Jenis dan Sumber Data}

Jenis data dalam Penelitian ini adalah data primer, menurut Indriantoro dan Supomo (1999)"data primer merupakan sumber data penelitian yang diperoleh secara langsung dari sumber asli( tidak melalui media perantara).Sumber data dalam penelitian ini berasal dari responden yaitu kepala satuan kerja perangkat daerah dan kepala bidang perencanaan pada satuan kerja perangkat daerah di Kota Sorong.

\section{HASIL ANALISIS DAN PEMBAHASAN}

\begin{tabular}{|l|c|c|c|}
\hline \multicolumn{1}{|c|}{ Uariabel } & $\begin{array}{c}\text { Alpha } \\
\text { Cronbach } \text { 's }\end{array}$ & $\begin{array}{c}\text { Batas } \\
\text { Reliabilitas }\end{array}$ & ket \\
\hline APBD yang berbasis kinerja (Y) & 0,706 & 0,6 & Reliabel \\
Komitmen dari seluruh komponen & 0,760 & 0,6 & Reliabel \\
Organisasi (X1) & & & \\
Penyempurnaan sistem Adminitrasi (X2) & 0,735 & 0,6 & Reliabel \\
Sumber daya yang cukup (X3) & 0,666 & 0,6 & Reliabel \\
Penghargaan (Reward)yang jelas (X4) & 0,757 & 0,6 & Reliabel \\
Sanksi yang tegas (X5) & 0,741 & 0,6 & Reliabel \\
\hline
\end{tabular}

sumber : hasil penelitian tahun 2015(data diolah)

\section{Uji Mulkolinieritas}




\begin{tabular}{|l|c|c|}
\hline \multicolumn{1}{|c|}{ Collinearity Statistics } \\
\multicolumn{1}{|c|}{ Model } & Tolerance & VIF \\
\hline 1. (Contant) & & \\
Kepemimpinan dan komitmen &, 491 & 2,035 \\
Penyempurnaan sistem administrasi &, 553 & 1,807 \\
Sumber daya yang cukup &, 769 & 1,300 \\
Penghargaan(pushment) &, 866 & 1,155 \\
Hukuman (reward) &, 916 & 1,092 \\
\hline
\end{tabular}

sumber : Hasil Penelitian tahun 2015 (data diolah)

17 Hasil Uji F

\begin{tabular}{|c|c|c|c|c|c|}
\hline Model & Sun of Squares & df & Mean Square & $\mathbf{F}$ & Sig \\
\hline $\begin{array}{ll}\text { 1. } & \text { Regression } \\
& \text { Residual } \\
\end{array}$ & $\begin{array}{l}206,520 \\
228,751 \\
\end{array}$ & $\begin{array}{l}5 \\
64 \\
\end{array}$ & $\begin{array}{r}41.304 \\
3,574 \\
\end{array}$ & 11,556 & .000 (b) \\
\hline Total & 435,271 & 69 & & & \\
\hline
\end{tabular}

Sumber : Hasil Penelitian tahun 2015 (data diolah)

Nilai $t$ hitung

\begin{tabular}{|c|c|c|c|c|}
\hline Variabel & $t$ hitung & $t$ tabel & Signifikansi & Keputusan \\
\hline $\begin{array}{l}\text { Kepemimpina } \\
\text { \&Komitmen }(\mathrm{X} 1)\end{array}$ & 2.290 & 2,00 &, 025 & H0 ditolak \\
\hline $\begin{array}{l}\text { Penyempurnaan } \\
\text { sistem } \\
\text { Administrasi } \\
\text { (X2) }\end{array}$ & 0,769 & 2,00 & ,445 & H0 Diterima \\
\hline $\begin{array}{l}\text { Sumber daya } \\
\text { yang cukup (X3) }\end{array}$ & 0,827 & 2,00 & ,411 & H0 Diterima \\
\hline $\begin{array}{l}\text { Penghargaan } \\
\text { yang jelas (X4) }\end{array}$ & 1,313 & 2,00 & , 194 & H0 Diterima \\
\hline $\begin{array}{l}\text { Sanksi yang tegas } \\
\text { (X5) }\end{array}$ & 4,486 & 2,00 &, 000 & H0 Ditolak \\
\hline
\end{tabular}

Sumber : Hasil Penelitian Tahun 2015 (data diolah)

Hasil Analisis Koefisien Determinasi

\begin{tabular}{|l|l|l|l|l|l|}
\hline Model & R & R Square & $\begin{array}{l}\text { Adjusted R } \\
\text { Square }\end{array}$ & $\begin{array}{l}\text { Std.Error of } \\
\text { The Estimate }\end{array}$ & $\begin{array}{l}\text { Durbin } \\
\text { Watson }\end{array}$ \\
\hline 1 & 689 & 474 & 433 & 1.891 & 1.428 \\
\hline
\end{tabular}

Sumber : hasil penelitian tahun 2015 (data diolah)

\section{PEMBAHASAN UJI HASIL DATA}

Pada hasil penelitian ini menunjukkan pengaruh kepemimpinan dan komitmen dari seluruh komponen organisasi terhadap APBD berbasis kinerja adalah positif dan tidak signifikan. Pengaruh ositif terlihat dari koefisien regresi komitmen dari seluruh komponen organisasi sebesar 0,196 dan signifikan dimana tingkat signifikan lebih kecil dari pada $0,05(0,025<0,05)$ nilai t hitung dan lebih besar dari pada t tabel $(0,196>1,780)$.

Pada hasil penelitian ini menunjukkan pengaruh penyempurnaan sistem administrasi terhadap APBD berbasis kinerja adalah positif dan signifikan.Pengaruh positif terlihat dari keofisien regresi penyempurnaan sistem administrasi sebesar 0,085 dan signifikan dimana tingkat signifikan lebih besar dari pada $0,05(0,445>0,05)$ nilai $t$ hitung dan lebih kecil dari pada nilai $t$ tabel $(0,769<1,780)$.

Pengaruh sumber daya yang cukup terhadap penyusunan APBD berbasis kinerja adalah positif dan signifikan. Positif terlihat dari koefisien regresi sumber daya yang cukup sebesar 0,107 dan signifikan 
dimana tingkat signifikan lebih kecil dari pada $0,05(0,411>0,05)$ dan nilai t hitung lebih besar dari pada nilai t tabel $(0,202<1,780)$.

Pengaruh faktor penghargaan (reward) yang jelas terhadap APBD berbasis kinerja adalah positif dan tidak signifikan. Pengaruh positif terlihat dari koefisien regresi penghargaan (reward) yang jelas sebesar 0,202 dan tidak signifikan dimana tingkat signifikan lebih besar dari pada $0,05(0,194>0,05)$ dan nilai t hitung lebih kecil dari pada nilai t tabel $(1,313<1.780)$.

Pengaruh sanksi yang tegas terhadap penyusunan APBD berbasis kinerja adalah positif dan tidak signifikan. Pengaruh positif terlihat dari koefisien regresisanksi yang tegas sebesar 0,782 dan tidak signifikan dimana tingkat signifikan lebih kecil dari pada $0,05(0,000<0,05)$ dan nilai thitung lebih besar dari pada nilai t tabel $(4,486>1,780)$.

\section{KESIMPULAN DAN SARAN \\ 6.1 Kesimpulan}

Berdasarkan pembahasan dari hasil penelitian, maka dapat diambil kesimpulan bahwa secara simultan faktor kepemimpinan dan komitmen dari seluruh komponen organisasi penyempurnaan sistem administrasi, sumber daya yang cukup, penghargaan (reward) dan sanksi (punishment) berpengaruh signifikan terhadap penyusunan APBD berbasis kinerja. Sedangkan secara parsial faktor penyempurnaan sistem administrasi, dan sumber daya yang cukup, penghargaan yang jelas berpengaruh positif dan signifikan terhadap penyusunan APBD berbasis kinerja. Namun kepemimpinan dan komitmen dari seluruh komponen organisasi dan sanksi yang tegas positif dan tidak signifikan berpengaruh terhadap penyusunan APBD berbasis kinerja, akan tetapi semua variabel independen mempunyai pengaruh positif terhadap variabel dependen.

\subsection{Saran}

Pemerintah kota sorong perlu melaksanakan sosialisasi tentang penyusunan anggaran berbasis kinerja untuk meningkatkan pemahaman SDM serta perlu menerapkan sistem pemberian penghargaan atas pencapaian kinerja dalam pelaksanaan anggaran dan penetapan kinerja sebagai motivasi untuk meningkatkan prestasi kerja, serta sanksi yang tegas atas ketidaktaatan dalam menjalankan tanggungjawab pekerjaan untuk meningkatan prestasi kerja. Selain itu yang paling penting adalah setiap SKPD harus memiliki data kuantitatif untuk memperoleh informasi tentang berbagai program yang menghasilkan output dan outcome yang diharapkan serta mengimplementasikan sistem aplikasi yang terintegrasi antara perencanaan, pelaksanaan dan pelaporan sehingga proses monitoring dan evaluasi menjadi baik dilaksanakan.

\section{DAFTAR PUSTAKA}

Asmoko,Hindri, 2006, Pengaruh Penganggaran Berbasis Kinerja terhadap Efektivitas Pengendalian, Jurnal Akuntansi Pemerintah, Vol 2 No 2,Jogja karta.

BPKP, 2000, Pengukuran Kinerja: Suatu Tinjauan Pada Instansi Pemerintah,Jakarta BPKP, 2005, Pedoman Penyusunan Anggaran Berbasis Kinerja (Revisi),Jakarta

Bastian, Indra.2001.Akuntansi Sektor Publik Indonesia.BPFE. Yogyakarta

Anggarini, Yunita dan B. Hendra Puranto. 2010. Anggaran Berbasis Kinerja. Penyusunan APBD Secara Komprehensif. UPP STIM YKPN. Yogyakarta

Ditjen Perbendaharaan Departemen Keuangan R.I,2008,Modul Pengelolaan Keuangan Negara.Jakarta

Erlinadan Mutyani.Sri.2007.Metodologi Penelitian Bisnis Untuk Akuntansid an Manajemen.hal. 53. USUpress,Medan Indriantoro dan Supomo,1999.Metodologi Penelitian Bisnis Untuk Akuntansi dan Manajemen, Edisi Pertama,BPFE Yogyakarta.

Ikhsan, Arfandan Ghozali.Imam,2006,Metodologi Penelitian Untuk Akuntansi Dan Manajemen, PT.Madju MedanCipta,Medan.

Kementerian Negara Perencanaan Pembangunan Nasional Bappenas, 2006, Manajemen Yang Beorientasi Peningkatan Kinerja Instansi Pemerintah,Jakarta

Kuncoro, Mudrajad. 2003. Metode Riset Untuk Bisnis Dan Ekonomi, Erlangga, Jakarta.

Lubis,Ade Fatma.et.al.2007.Aplikasi SPSS (Statistical Product and Service Solutions) untuk Penyusunan Skripsi dan tesis.USUpress, Medan 